\title{
Neutrophil Erythrophagocytosis and Neutrophil Erythrocyte Rosetting in Paroxysmal Cold Haemoglobinuria
}

\section{Paroksismal Soğuk Hemoglobinüride Nötrofil Eritrofagositozu ve Nötrofil-Eritrosit Rozetleşmesi}

Krishnappa Amita

Shivashankar Vijay Shankar Mallika Rajshekar Kalmood Channagangappa Shimoga Indira

Department of Pathology, Adichunchanagiri Institute of Medical Sciences Karnataka, India

Geliş Tarihi/Received: 09 June 2018 Kabul Tarihi/Accepted: 09 August 2018

\begin{abstract}
Öz
Paroksismal soğuk hemoglobinüri (PSH), spesifik olmayan semptomlar nedeniyle öntanıda göz önüne genellikle alınmayan nadir görülen bir otoimmün hemolitik anemidir. Periferik yaymada nötrofilik eritrofagositoz ve nötrofil eritrosit rozet oluşumu, özellikle $\mathrm{PCH}$ 'de olmak üzere otoimmün hemolitik anemide nadiren bildirilen bir bulgudur. Akut başlangıçlı ateşi olan ve bu olağandışı periferik yayma bulgularını paroksismal soğuk hemoglobinüri açısından değerlendirdiğimiz 25 yaşında bir kadın hastayı sunduk. Nötrofil eritrosit rozetinin varlığı ve periferik yaymada nötrofillerle eritrofagositoz varlığı halinde patolog, PSH tanısı açısından dikkatli olmalıdır ve bu bulgular gereksiz araştırmalardan kaçınmaya yönlendirebilir.
\end{abstract}

Anahtar Kelimeler: Otoimmün hemolitik anemi, soğuk hemolizin, antikori intravasküler, donath lantsteiner

\begin{abstract}
Paroxysmal cold haemoglobinuria is an uncommon form of autoimmune haemolytic anemia the diagnosis of which is usually not considered at the initial presentation due to nonspecific symptoms. Neutrophilic erythrophagocytosis and neutrophil erythrocyte rosette formation in peripheral smear is an uncommon finding which has been reported rarely in autoimmune haemolytic anaemia, especially paroxysmal cold haemoglobinuria. We report a case of a 25-year-old female who presented with acute onset fever and in whom these unusual peripheral smear findings directed the pathologist to initiate the work up for paroxysmal cold haemoglobinuria. Being vigilant about the presence of neutrophil erythrocyte rosette and erythrophagocytosis by neutrophils in peripheral smear will guide pathologist towards initiating a workup for paroxysmal cold haemoglobinuria and avoiding unnecessary investigations.
\end{abstract}

Key words: Autoimmune haemolytic anaemia, cold haemolysin, antibody, intravascular, Donath Landsteiner

\section{INTRODUCTION}

Paroxysmal cold haemoglobinuria $(\mathrm{PCH})$ is a type of cold agglutinin induced autoimmune haemolytic anemia (AlHA) characterized by intravascular haemolysis mediated by biphasic haemolysin of IgG type (1). This cold reacting antibody binds to $p$ antigen on RBC at cooler temperature and upon reaching the warmer central circulation at 37-degree Celsius leads to compliment mediated haemolysis.

In earlier part of 18th century $\mathrm{PCH}$ was considered to be a disease of adults preceded by syphilis infection (2). However, recent reports show $\mathrm{PCH}$ to occur more frequently in children with acute onset of haemolytic anaemia (3). The disease is suspected based on clinical history of anemia, jaundice and haemoglobinuria. Donath Landsteiner test (DL) is the gold standard diagnostic test. Presence of erythrocyte rosetting mostly by monocytes and massive erythrophagocytosis in peripheral smear has been reported very rarely in $\mathrm{PCH}$ (4-6). Here in we report a rare case of fatal $\mathrm{PCH}$ with extensive erythrocyte rosetting by neutrophils and erythrophagocytosis in an adult female.

\section{CASE REPORT}

A 25-year-old female presented to the medicine outpatient department with history of fever with chills for eight days. She gave history of yellowish discolouration of face and sclera in the past two days. She also gave history of epistaxis which was on and off since birth, the last episode was two days back. There was history of vomiting and diarrhea, 7 to 8 times a day since previous day. Her appetite was reduced and she had generalized body pain, 
weakness and giddiness. On examination patient was febrile, pale and had icterus. Her pulse rate was 96 per minute. Blood pressure in supine position was $100 / 70 \mathrm{~mm} / \mathrm{Hg}$. Respiratory system, cardiovascular system, per abdominal system and central nervous system were unremarkable on examination. Based on this these findings two provisional diagnosis were considered 1. viral hepatitis \& 2. acute gastroenteritis. Laboratory investigations revealed following findings: $\mathrm{Hb}-4 \mathrm{gm} / \mathrm{dl}$. Mean corpuscular volume was $102 \mathrm{fL}$, platelet count was lakh/cumm, RBC count - 1.5 million/dl, peripheral smear RBC were reduced in number, normocytic normochromic, few polychromatophils, target cells and occasional nucleated RBC's (01/100 WBC). WBC's showed mild left shift in neutrophilic series. Erythrocytes were seen surrounding the neutrophils forming erythrocyte neutrophil rosettes. (Fig 1, 2 ). These rosettes showed multilayering of RBC around the neutrophils. At many places the neutrophil which was surrounded by RBC showed evidence of erythrophagocytosis. (Fig 3). Neutrophils and mononuclear cells were showing erythrophagocytosis. (Fig 4). LDH was 2280 IU/L. Indirect bilirubin was $5.5 \mathrm{mg} / \mathrm{dl}$. Ferritin level was $320 \mathrm{ng} / \mathrm{ml}$. Fibrinogen study was not done. Based on the peripheral smear and the biochemical test a diagnosis of haemolytic anemia possibly paroxysmal cold haemoglobinuria was suggested and a direct coomb's test (DCT) and DL test was advised.

VDRL Test was negative, DCT was positive with polyspecific Anti IgG and Anti C3d with ice cold saline wash. DCT was negative with routine normal room temperature saline wash. The Donath Landsteiner test was performed and found to be positive. Hence a final diagnosis of paroxysmal cold haemoglobinuria was made. Repeated attempts for blood grouping failed, patient was referred to higher centre where she succumbed to death.

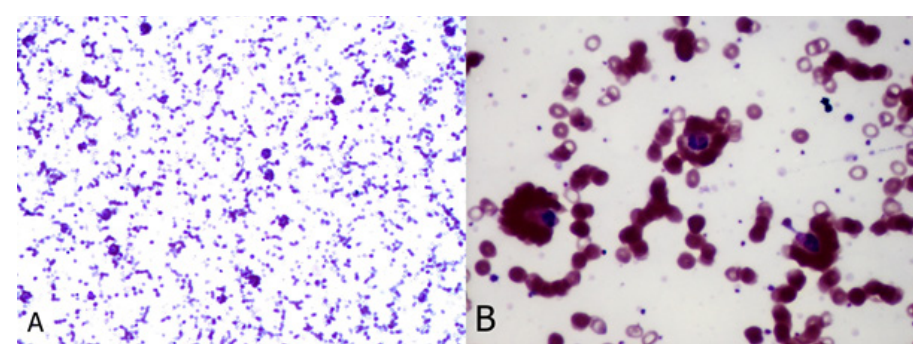

Figure 1. A \& B: Peripheral smear showing neutrophil erythrocyte rosetting in case of paroxysmal cold haemoglobinuria. (Leishman stain, x $40 \&$ x 400)

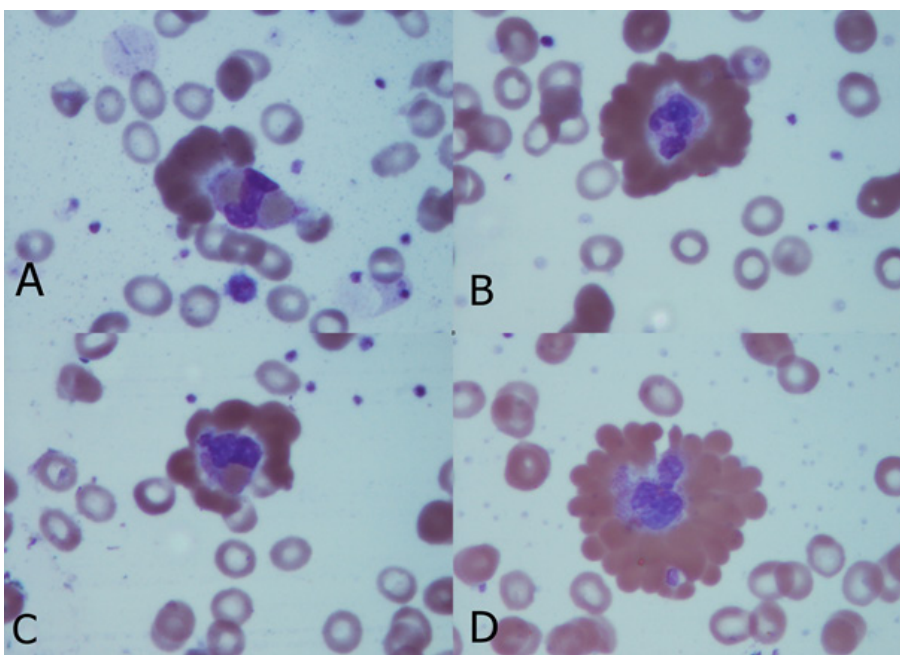

Figure 2. Peripheral smear showing rosettes in varying stages of formation. A: Unilayered neutrophil erythrocyte rosette, B: partial neutrophil erythrocyte rosette, C: Complete neutrophil erythrocyte rosette, D Multilayering of erythrocytes in neutrophil erythrocyte (Leishman, x 400)

\section{DISCUSSION}

$\mathrm{PCH}$ belongs to the spectrum of cold agglutinin induced AlHA which encompasses cold agglutinin syndrome and $\mathrm{PCH}$. $\mathrm{PCH}$ occurs commonly in children and is mediated by biphasic IgG antibody. These antibodies bind to $p$ antigen on the surface of erythrocytes in the cooler temperature of 0 to 4 degree Celsius and cause intravascular haemolysis on reaching the warmer, central circulation at 37

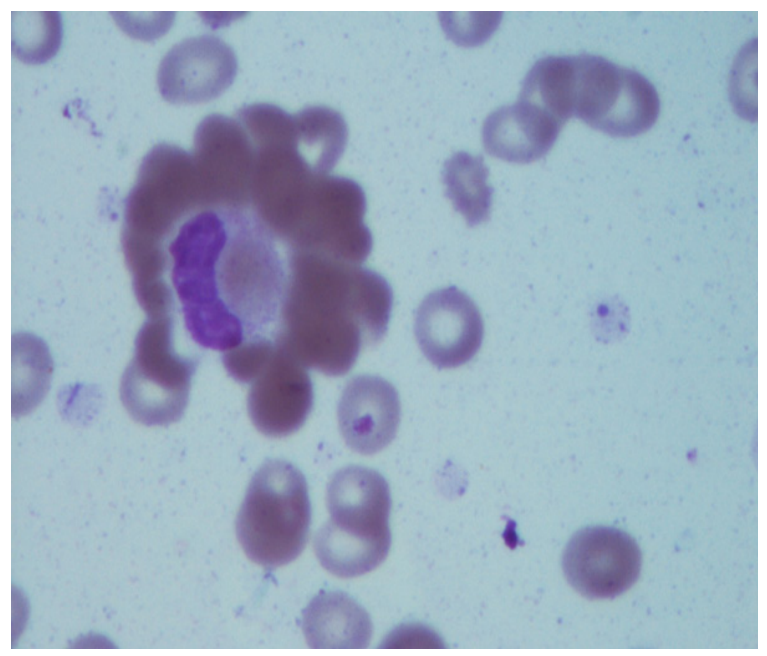

Figure 3. Peripheral smear showing erythrophagocytosis by neutrophil entrapped in the rosette in case of paroxysmal cold haemoglobinuria. (Leishman, x 400) 


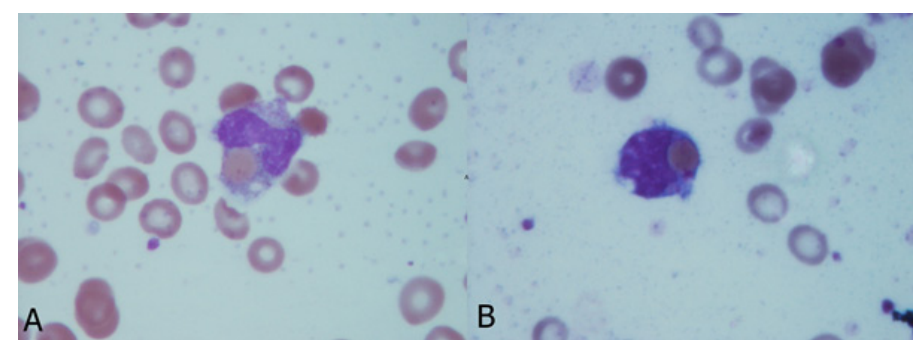

Figure 4. A Peripheral smear showing erythrophagocytosis by neutrophil. B: Erythrophagocytosis by mononuclear cell.

degrees Celsius (1).

Previously $\mathrm{PCH}$ was known to occur secondary to syphilis. However, with decrease in the prevalence of syphilis, this association is rare. However, $\mathrm{PCH}$ now is known to occur following viral exanthem, immune dysregulation or lymphoproliferative disorder. The patient usually presents with acute onset fever with chills, weakness, pallor, jaundice and high coloured urine attributed to haemoglobinuria. The haemoglobinuria may be episodic and go unnoticed. At times the symptoms may be nonspecific at initial presentation leading to delay in diagnosis and unnecessary investigations.

Laboratory investigations reveal a picture corroborating an episode of haemolysis with evidence of anaemia, raised total and indirect bilirubin, $\mathrm{LDH}$, reticulocytosis. The urine may show granular brown RBC cast and positive benzidine test. However, in our case, this finding was missing as the patient did not have an episode of haemoglobinuria at presentation. The peripheral smear findings were characteristic in the present case. Apart from the feature of haemolysis, there was evidence of marked erythrophagocytosis and erythrocyte neutrophil rosetting.

Erythrophagocytosis by neutrophils in peripheral smear though an uncommon finding, is a strong predictor towards the diagnosis of $\mathrm{PCH}$ (5). Erythrophagocytosis by neutrophils in peripheral smear has been reported rarelyAIHA. PCH, spider bite, quinine therapy, erythroblastosis fetalis, incompatible blood transfusion and potassium chlorate poisoning (7). Its presence in peripheral smear is a prominent indicator of AIHA. Chandrashekhar et al proposed that the presence of erythrophagocytosis in peripheral smear should alert the pathologist for a diagnosis of $\mathrm{PCH}$. (5). Fadeyi EA reported two cases of $\mathrm{PCH}$ occurring in children and emphasized the presence of erythrophagocytosis as an important indicator of $\mathrm{PCH}$ (8). Similarly, erythrocyte neutrophil rosette is also an extremely rare phenomenon. The first description of this goes back to 1976 when Petitt et al mentioned erythrocyte neutrophil rosette in EDTA anticoagulated blood of a 28-year-old female who was a known case of chronic autoimmune haemolytic anemia with exacerbations (9). The authors failed not only in depicting the exact pathogenesis but also were unable to demonstrate the phenomenon in heparin or citrated blood. The interaction of Fc receptor of neutrophil with $\lg G$ coated on $\mathrm{RBC}$ s results in rosette formation. For the neutrophil RBC rosette to form, the antibody titre should be much higher and hence its presence usually indicates a severe form of disease and needs immediate intervention $(9,10)$.

Due to the rarity of phenomenon, the exact pathogenesis is not known. However certain invitro studies have proposed that monocyte erythrocyte rosette is more likely to occur due to high antibody dependant cell mediated cytotoxicity in monocytes. However, interestingly monocyte erythrocyte rosettes have not been reported till date. On the contrary, neutrophil erythrocyte rosette has been reported infrequently in AlHA and $\mathrm{PCH}$. It has been proposed that high titre is required for the neutrophil $\mathrm{RBC}$ rosette to form in vitro which may be the plausible mechanism for the fatality in the present case $(11,12)$. Whatever the cause, presence of rosette and erythrophagocytosis are important indicators of $\mathrm{PCH}$. Few reports mention in vivo occurrence of neutrophil erythrocyte rosette in phosphate buffered saline. Schulman et al suggested that the rosette in their case was due to $\lg \mathrm{G} 3$ antibody which had high affinity (11).

Since its description by Donath and Landsteiner in 1904, Donath Landsteiner test is still the gold standard diagnostic tool for $\mathrm{PCH}$. Since the $\mathrm{DL}$ antibody, a biphasic lgG binds to RBCs at cooler temperature, it is imperative to maintain the temperature of blood sample at $37 \mathrm{C}$ to prevent adsorption of antibody on RBC (13).

The clinical course of the disease is variable, many following a benign course and very few rapidly progressing to fatal disease. Despite of the initial severity of the acute episodes, the disease is transient and recurrences are rare. The management is aimed at reducing the symptoms due to anemia and preventing complications due to intravascular haemolysis. Use of corticosteroids and rituximab is restricted to intractable cases, however their role has not been well established due to rarity and brief course of the disease. 


\section{CONCLUSION}

Erythrophagocytosis and neutrophil erythrocyte rosetting are important predictors for the diagnosis paroxysmal cold haemoglobinuria. Their presence should prompt the pathologist for ordering a confirmatory DL antibody test. It is important for the pathologist and the physician to be aware of this rare disease as early diagnosis and appropriate management would prevent catastrophes as in the present case.

Conflict of interest: Authors declare that there is no conflict of interest between the authors of the article.

Financial conflict of interest: Authors declare that they did not receive any financial support in this study.

Address correspondence to: Shivashankar Vijay Shankar, Department of Pathology, Adichunchanagiri Institute of Medical Sciences, BG Nagara, Nagamangala taluk, Mandya District, Karnataka, India. 571448

E-mail: vijayshankarpatho@gmail.com

Telephone number: 9845357933

\section{REFERENCES}

1. Slemp SN, Davisson SM, Slayten J, et.al. Two case studies and a review of paroxysmal cold hemoglobinuria. Lab Med 2014;45(3):253-8.

2. Sokol RJ, Booker DJ, stamps R. Paroxysmal cold hemoglobinuria and the elusive Donath-Landsteiner antibody. Immunohematology 1998;14:109-12.

3. Makkar A, Patradoon-ho P, Ambler R. Paroxysmal cold haemoglobinuria in an 18-month-old child during an australian spring. J paediatr child health 48:710.

4. Yadav G, Rahman K, Gupta R. Neutrophil Erythrocyte Rosettes: An Unusual Manifestation of Autoimmune Hemolytic Anemia. Indian Journal of Hematology \& Blood Transfusion 2016;32(Suppl 1):309-10.

5. Chandrashekar V, Soni M. Florid erythrophagocytosis on the peripheral smear. J Lab Physicians 2012;4:59-61.

6. SampagarA, Bartakke S, Lukade U, et.al. Erythrophagocytosis by Neutrophils in Paroxysmal Cold Hemoglobinuria. Ann Hematol Oncol 2017; 4(5): 1151.

7. Mukhopadhyay S, Keating L, Souid A. Erythrophagocytosis in Paroxysmal Cold Hemoglobinuria. American Journal of Hematology 2003;74:196-7.

8. Fadeyi EA. Paroxysmal Cold Hemoglobinuria: Not an "Uncommon" Disease Anymore. J Hematol Thrombo Dis 2014;2:162.

9. Pettit JE, Scott J, Hussein S. EDTA dependent red cell neutrophil rosetting in autoimmune haemolytic anaemia. $J$ Clin Pathol1976;29:345-6.

10. Mirchandani I, Palutke M, Kithier K, et.al. In vitro neutrophilerythrocyte rosette formation mediated by a serum factor (IgG). Am J Hematol 1984;17(1):79-83.

11. Schulman S, Awad MM, Kuter DJ. Neutrophil-erythrocyte rosettes in autoimmune hemolytic anemia. Am J Hematol 2013;88(4):333-4.

12. Shaw GM, Levy PC, Lobuglio AF. Re-examination of the EA rosette assay (Ripley) for Fc receptor leucocytes. Clin Exp Immunol. 1979;36:496-501.

13. Sokol RJ, Hewitt S. Autoimmune haemolysis: A critical review. Crit Rev Oncol Hematol 1985;4(2):125-54. 